\title{
THE RESULTS OF PRIVATIZATION OF THE SAHARA BANK LIBYA
}

\author{
Goranka Knežević \\ Singidunum University, Belgrade, Serbia \\ Abubaker Erabaa \\ Azzaytuna University, Libya \\ Vladan Pavlović ${ }^{1}$
}

Univerzitet u Prištini, Ekonomski fakultet, Kosovska Mitrovica, Srbija

\begin{abstract}
The purpose of this paper is to evaluate privatization process, obstacles and difficulties faced by the Libyan economy, particularly financial institutions, mainly banks. Despite the fact that goals of privatization proclaimed by the Government dereliction in the area of developing financial markets and making the economy more efficient, it is the process with many obstacles. Privatization has also been motivated with political reasons and all the effects of it in this paper will be considered through this prism. In this paper we analyzed the privatization of one of the largest commercial banks in Libya, named Sahara bank. This bank was purchased by French BNP Paribas bank and the results of this privatization supported the idea that when privatization process is led efficiently and smoothly it affects the entity its employees and economy as a wholpositively affects the entity, its employees and economy as a whole.
\end{abstract}

Keywords: privatization process, financial institution, firm performance.

\section{INTRODUCTION}

Privatization in less developed countries is motivated with different reasons than privatization in developed economies. In developed economies primary motive is less efficiency of state owned companies than privately owned companies. In less developed countries besides the political reasons, motives for privatization could be more general, like promoting the efficiency of the economy as a whole. There were several stages of privatization process in Libya. The first one happened in 1987 as a result of a huge drop in oil prices. Libyan economy depends most on oil products, so the decrease in prices affected the economy. Government in Libya allowed private sector investments for the first time. The sectors affected were retail trade, services and light industry sectors. The second stage happened in 1992 and the same motives lie behind this privatization.

For the first time joint stock companies were organized in Libya. In 2003 the large privatization program in Libya started. It was the Wealth distribution program that gave possibility of employees and citizens to participate in the distribution of the oil benefits using the Peoples Committees. The distribution took the form of cash or shares. It

${ }^{1}$ vladan.pavlovic@pr.ac.rs

Vol. 17, бpoj 1/2015, cmp. 25-34 
seems that the privatization in Libya was process motivated by distributing the ownership rights to employees and by opening the market of this country for foreign investments. The financial sector of the economy was also affected by this last stage of privatization. Despite the fact that the development of financial sector influences the whole economy in Libya, it was also process driven by political reasons. Only several banks were privatized and the results were quite different. In most of the cases proclaimed objectives in financial sector were not attained.

In order to measure the results of privatization in Libya more specifically and not only theoretically, we develop the article idea through the following: differences between private sector banks and state banks were explained, we test the theoretical concepts of privatization using the case study method of the Sahara bank from Libya, and in the last section we present obstacles and problems of privatization of financial sector in this country.

\section{DIFFERENCES BEWEEN PRIVATE SECTOR BANKS AND STATE OWNED BANKS AS A PREREQUISITE FOR PRIVATIZATION IN LYBIA}

Private and state sector banks have many differences between themselves and these differences serve as a primary motive for privatization in Libya and other Arab countries (Arab Banks Union, 1993). Some of these differences are described in the next paragraphs.

The nature of banks ownership has its effects on the relationship of these banks with the Central Bank. When banks are state owned they do have specific relationship where Central Bank serves as a sponsor and not the supervisor (Arab Banks Union, 1993). As with regard to the banks in Libya before privatization, they have been characterized by single state ownership and a supporter of one state policy. This therefore, has an effect on the competition process among such banks. This impression consequently reflected on a drop of the level of the services provided by these banks. In addition, they maintained the overwhelming unjustified caution in the course of their dealings and credit policies and lacking the exertion of any efforts for seeking investment opportunities or developing themselves.

The difference between the state and private banks are shaped by several aspects such as: operating goals, bank management, lending policies, collection policies and control. In some studies various researchers clarify these differences.

The private banks mostly intend to achieve the maximum possible margin of profits (enhancing their returns), while we find that the state 
owned banks aim toward accomplishment of social and economic goals, such as the policy of creation of employment opportunities and financing the public projects, without due consideration of their financial position or the ability of these projects to provide adequate return. This is due to the fact that state in this case is the guarantor for these loans (Tewfik, A. \& Alatifa, N, 2006).

As with regard to the management, the private banks usually follow intact and sound policies which are more effective than that followed and applied by the state banks. This is in particularly, clear in the developing countries. Privately owned banks utilize a set of incentives, regulations and means which can secure the efficiency of the management of such banks, while the management of the state banks is subject to huge state pressure in directing the credit policy, which therefore, leads into a poor and bad management, and hence, the introduction of non-efficient decisions.

The main difference also lies in respect of lending policy. These differences come in the form of credit granting, where the credit awarding by private banks is subject to the thorough study of the clients financial position. We found that credit award decision in state banks is sometimes subject to political considerations. In private banks, for instance, the officials of the bank are questioned about the credits they offer and on the performance and the loans return which such officials grant under their own authority. In state banks, however, there is a tolerance in loans direction to individuals and institutions, specially, if the matter is concerned with state owned projects, where such loans are offered under political pressures.

The policy of loans collection is a very significant especially when bank is owned by the state and client is huge state enterprise. Many stumbled debts which are difficult to recall for payment by the banks is a very risky issue, which leads into a rise in the cost of the funds of the banks and of the banks' ability to grant credits. It also, causes a drop in the banks' profit margin, increase of the problems between banks and projects' clients (Wasfe, H., 1996).

In privately owned banks certain incentives for the banks' employees exist and encourage them to carefully study the various statuses of the borrowers. They also carefully study safety of the loans granted to such borrowers, and the extent of the capacity and ability of the borrower to repay the loan/loans. These incentives and pressures make it easy to collect the loans granted by the private banks. These banks are careful and devoted to applying follow up systems of their customers to ensure that they will pay back the funds granted to them. This situation would reduce the minimum loan losses which may be incurred by the 
private bank. These banks apply a persistent control system, regarding the control and follow up processes, both of bank's transactions and on workers' performance, as well as on the whole management and without any courtesy or favors.

Regarding the loans collection policy in state banks in developing countries; we can conclude that this is characterized with the least interest from the officials granting the loans. This is in fact is due to several reasons such as:

- The state owned banks are subject to political pressures to grant loans. This makes it difficult to recollect such loans, because of directing their resources for financing state projects, on the justification that that the borrower is a public company, which the state is in this case the guarantor of both the loans and company (Tewfik, A. \& Alatifa, N.,2006).

- The state owned banks lack the technically trained employees capable of following up the collection of the loans, since such action is attributed to staff that lacks the efficiency and charisma and trust to enforce such an important job.

- In the state banks, the control systems are usually poor and insufficient; there is a lenity in applying such controls, which eventually, negatively affects the banks' transactions and banks performance.

All of these differences between state and private banks, allow us to conclude that in the financial sector of the economy which is driven by bank loans, privatization process could be very good solution.

\section{GROUNDS, REQUIREMENTS AND OBJECTIVES OF THE PRIVATIZATION PROCESS IN LIBYA}

The banking sector privatization process is a very complicated and sensitive process, because of the vital and significant role played by this sector in promoting the economy compared with the other economic activities. This is due to the following reasons explained in the next section.

The banking sector and its role in the success of the reconstruction of the economy and in promoting the level of the development of the local economy and promote the trust of the international investors in it; would lead to the conclusion that any financial or administrative defect in privatization would have negatively affected banking sector.

The trust represent the most and main resource of doing business in this sector of economy. The banks attract and keep the assets of the clients whether individuals, companies or public or private institutions, 
preserving the trust of the banks' customers, and encouraging them for more deposits and for seeking more savings (Swailem, M. 2001).

Compared with the process of privatization of the other entities in various sectors, the privatization of the banking sector is different as the banking institutions are dealing directly with the assets of their clients,. This means that such institutions deal with financial assets and they enjoy great dynamic freedom in investing these assets. This could have led to the creation of the risk on the economy. Implementation of the privatization program of the banking sector could also contribute to that risk when it is not efficiently executed.

In this regard, the Central Bank of Libya intends behind the privatization program to accomplish the following objectives:

- Realization of the banking competency both on the national and international levels, industries,

- Keeping pace with the events and developments in the banking

- Promoting the efficiency of the performance levels through the optimal utilization of the work force,

- Support of the trust and transparency in the banking system in a way leading to the improvement of the monetary system performance.

According to some authors the other objectives reached by the privatization are boosting the banking supervision and organization (Ennajar, S., 1994). According to this author there must be a supervision system established by the Central bank for organizing the economic policies, including the monetary and credit policies. The Central Bank has responsibility for observation or application of the accounting standards, international auditing directions, and should reconsider the rules and legislation etc. Central Bank has a role to issue bank licenses that secure the adequate capital safety and setting limits to lending processes.

\section{LIBYAN ECONOMY AND PRIVATIZATION PROCESS IN BANKING SECTOR- CASE STUDY OF SAHARA BANK}

One of the first companies that underwent the privatization process was Sahara bank from Libya. This bank was owned by the Central bank of Libya and in the year 2001 Central bank was forced to take the necessary steps to sell its share in Sahara bank. Central Bank decided to increase the bank capital to 126 million Libyan dinars by selling 12.600.000 shares of 10 dinars each in 2005. The buyer was BNP Paribas Bank from France. It purchased 19\% of capital spending 145 million Euro with the possibility to increase its share to $51 \%$ in the $3-5$ year period. 
From the graph 1 we can make a conclusion that after privatization (after 2004) Sahara bank increased its total assets from 2.102 million Libyan dinars to the level of 11.388 million Libyan dinars which was an increase of $414 \%$. BNP Paribas as a strategic partner helped Sahara bank to increase its assets and to serve more clients and to become the first and the largest Libyan commercial bank. This is not only due to the fact that BNP Paribas invested additional assets but also we assume that the accounting policies for financial instruments were changed. We predict without support of the valid argument that before privatization Libyan banks recognized financial instruments at historical cost, and after privatization new fair value policy has probably been applied. Fair value policy had an effect on financial instruments in terms of increasing their value, and the value of total assets (Knezevic, G.\& Pavlovic, V., 2008).

\section{Graph 1.: The total assets of Sahara bank from Libya in the period 2004-2009}

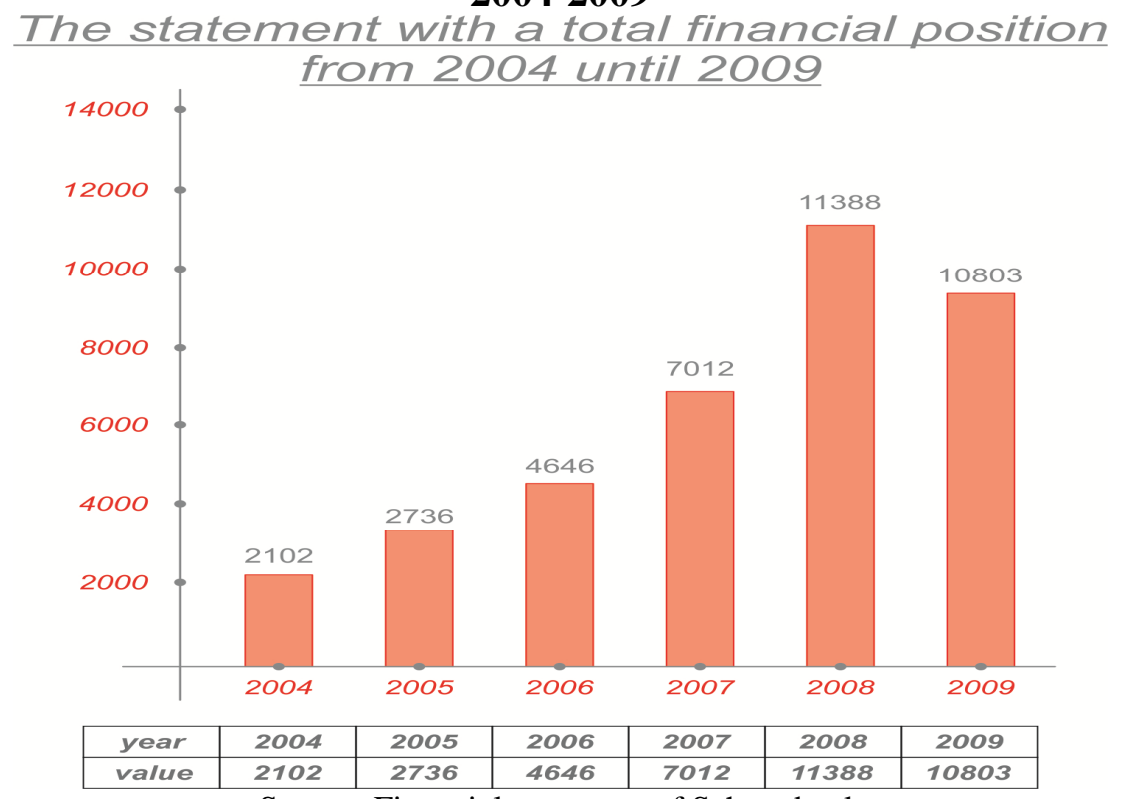

The total credit activity value also indicates (see graph 2) whether the privatization affects banks lending capacity. Graph No.2 shaws that the total value of Libyan dinars considered to be spend for financing the clients was 1.089 million Libyan dinars in the year 2004. In the last year 2009 it rose to the level of 1.803 million Libyan dinars which represents an increase of $66 \%$. 
Graph 2.: Total credit activity of Sahara Bank in the period 20042009

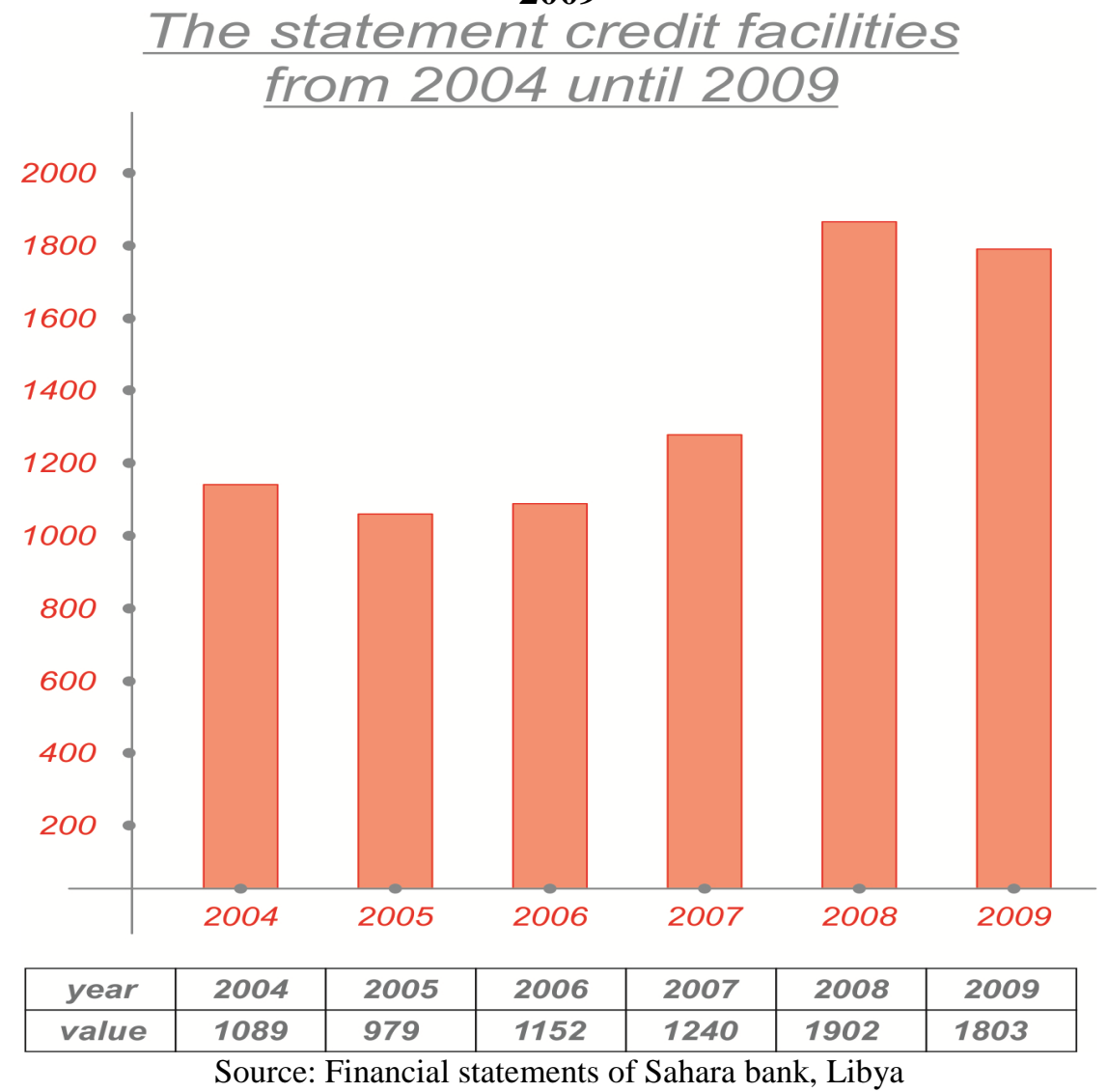

According to the above graphical presentation and numbers we can conclude that before the Civil War in Libya the financial position of Sahara bank and its lending capacity was at the highest level among all other banks in Libya.

Aslo, the results of privatization can be judged based on performance indicators (see Table 1):

Table 1.: ROA and ROE indicators for the Sahara Bank in the period 2004-2009

\begin{tabular}{||r||r||r||r||r||r|r||}
\hline Year & 2004 & 2005 & 2006 & 2007 & 2008 & 2009 \\
\hline \hline ROA & $2.7 \%$ & $2.25 \%$ & $2.00 \%$ & $1.78 \%$ & $1.42 \%$ & $1.45 \%$ \\
\hline \hline Year & 2004 & 2005 & 2006 & 2007 & 2008 & 2009 \\
\hline \hline ROE & $28.6 \%$ & $29.20 \%$ & $42.70 \%$ & $43.00 \%$ & $65.40 \%$ & $69.00 \%$ \\
\hline
\end{tabular}


In the above table we can conclude that ROA decreased from $1,78 \%$ in the year 2007 to $1,42 \%$ in the first year after privatization and then it rose again to $1,45 \%$ in 2009 . This is not unusual for privatized banks. (Beck, T., Cull, R.; Jerome, A., 2005, page 12) explained that although that "this indicates a positive performance effect of privatization, it does not control for ...(ii) other bank characteristics and policies that might have changed after privatization". According to the results regarding ROE since 2007 it rose from $43 \%$ to extremely high $65 \%$ in 2008 and $69 \%$ in 2009. It is due to the fact that profit and capital increases at the same time, but profit increases more than capital, so the total effect was positive.

The above numbers show that privatization process had positive effects on this bank in the period of 4 years after the privatization. Among these things privatization and good strategic partner as it was BNP Paribas back then helped the privatized entity to establish better banking procedures, employees were trained and skilled to use sophisticated software and to prepare efficient and effective reports for the bank managers. All over all, this positive case of privatization in Libya shows us that when it is run smoothly and efficiently privatization can be one powerful instrument for promoting good corporate culture, skills and procedures on entity level and on the economy level as a whole.

\section{PRIVATIZATION OBSTACLES AND DIFFICULTIES}

A set of problems and difficulties are encountered in the course of privatization program in all Arab countries. These obstacles may hinder the accomplishment of the goals which the privatization intends to accomplish. Here we will review the most important obstacles that could limit the transformation program, which had to be addressed clearly. We concluded that the most of these problems and obstacles which ought to be dealt with and treated are:

- Labor surplus problem (privatization usually leads to the huge cut off program and reduction of wages costs in banks)

- Lack of existence of an organized security market (this fact makes impossible further development of private companies).

- Restriction to certain methods of privatization (only methods promoted by the Government are applied and they are not changed even when it's obvious that the results are not as good as expected and problems accumulate over time).

In a study about the obstacles encountered by the foreign investments, it has been shown that the most problems facing the foreign 
investors in Libya include :(The Central Bank of Libya-Economic review, 2004)

- Poor infrastructure,

- Poor local management,

- Poor data and financial information,

- Lack of sufficient guarantees,

- Business transactions depending on interpersonal relationships.

According to some researchers (Al Farsi,I. \& Almansouri, A.J., 2005) Libyan businessman in banking sector think that there is a lack of organized budget and weak accounting system which is still in place after privatization, banking procedures are very slow, lack of administrative stability exits as well as shortage of qualified labor.

\section{CONCLUSION}

In this article it was pointed out that the transition process in Libya is sophisticated marked by many problems and weaknesses such as political instability, flexible administrative procedures, unskilled labor and low level of technical resources for conducting finance operations. Despite these external factors, there are many positive effects of privatization in banking sector in Arab countries such as Libya. These factors are competitiveness of this sectors is enhanced, quality of banking services increase and larger portfolio of services is rendered to clients, better control system and procedures are developed, supervising function of Central Bank is developed and Central Bank redefine its position towards commercial banks. All over all, privatization in Libya before the Civil War developed with the average pace, and financial system in Libya has undergone serious changes. Using Sahara Bank as a case study we emphasize that total assets increase and that loan capacity of this bank rose as a direct positive effects of privatization

\section{REFERENCES}

1. AL Farsi. A.I. \& Almansouri., A.J. (2005): Privatization in the Libyan Economy, Center for economic researches, Benghazi

2. Arab Banks Union. (1993) The Specialized Arab Banks and Development of Arab Banks, Beirut

3. Central Bank of Libya (2004). Privatization and economic development in Libya the difficulties anticipated economic impacts , Economic Review, CBL, Libya

4. Ennajar,S. (1994) Financial policies and Arab financial marets in: Report of Arab Monetary Fund,pp 14-15, Dubai. 
5. Essadiq, T.\& Latifa,N (2006). Effort sand obstacles of privatization in Arab countries. Abu, Dubai

6. Knežević, G., Pavlović, V. (2008). Uticaj finansijskog sistema na izveštavanje o finansijskim instrumentima, Računovodstvo, god.52 (9/10), 7-28

7. Swailem, M.(2001) Analytical study of the movement of labor from the public banks, private banks and joint banks, Mansoura University, Faculty of Commerce, Mansoura.

8. Wasfe, H. (1996). The role of accounting in achieving the objectives of privatization, assessing the Egyptian experience, Journal of the Faculty of Commerce for Scientific Research, Alexandria University 